\title{
Instantaneous intake rates of 9 browse species by white- tailed deer
}

\author{
BEN H. KOERTH AND JERRY W. STUTH
}

\begin{abstract}
Instantaneous intake rate (IIR) and instantaneous nutrient intake rate (INIR) by tame white-tailed deer (Odocoileus virginianus) of 9 common browse species in south Texas were studied to determine if morphological properties of the plants were associated with intake rate, and if IIR and INIR correlated to preference ratings derived from percent time spent foraging a particular species and with total foliage consumed. Mean leaf mass showed a significant $(P<0.05)$ positive correlation to IIR $(r=0.75)$, INIR of neutral detergent fiber $(r=0.73)$, acid detergent fiber $(r=0.73)$, and acid detergent fiber nitrogen $(r=0.68)$. Mean leaf length showed a significant $(P<0.05)$ positive correlation to INIR of crude protein $(r=0.67)$. Thorn density showed no significant $(P>0.05)$ correlations to IIR or INIR. Leaf weight/stem weight ratio showed a significant $(P<0.05)$ positive correlation to IIR $(r=0.65)$ and INIR of acid detergent fiber nitrogen $(r=0.81)$. Rankings of IIR and INIR did not agree with preference indices based on weight of forage removed or amount of time spent browsing. Significant $(P<0.05)$ positive correlations for all trials between preference indices based on weight removal and time spent browsing $(r=0.73$ for new leaf development, $r=0.87$ for stem elongation, and $r=0.70$ for full leaf development) indicated these 2 techniques closely agreed on species rank.
\end{abstract}

Key Words: instantaneous intake rate, instantaneous nutrient intake rate, white-tailed deer, Odocoileus virginianus, browse

Browse is a major component of white-tailed deer (Odocoileus virginianus) diets in subtropical thornscrub woodlands in south Texas and northern Mexico. Although diet selection can vary between herds and with season (Arnold and Drawe 1979), numerous species of browse plants have been found to consistently make up a large part of deer diets in this area and several have been termed as preferred food plants (Davis 1952, Davis and Winkler 1968, Chamrad and Box 1968, Drawe 1968, Everitt and Drawe 1974, Arnold and Drawe 1979). Preferential selection for a species is hypothesized as being correlated with palatability as well as with availability (Willms 1978). Palatability has been defined as a plant characteristic that stimulates a selective response by foraging animals (Heady 1964) and may determine the duration of foraging and ingestion rate. Profitability of browsing should be directly and positively related to the amount of nutrients an animal can consume in a given time.

Morphological attributes of plants, including growth form, biomass of leaves, and presence of thorns or other forms of spinescence, may interact to defend foliage loss to herbivory (Willms 1978, Cooper and Owen-Smith 1986). While most browse plants in south Texas are armed with spines or thorns, many are considered important foods for white-tailed deer. Free-ranging herbivores select diets from plants that differ in canopy shape and architecture as well as temporal and spatial variation (Provenza and Balph 1990). More controlled environments are needed to differentiate individual plant parameters affecting intake rate. Our objectives were to determine if morphological properties of browse plants

\footnotetext{
Authors are research associate, Texas Agricultural Experiment Station, La Copita Research Area, Rt. 1 Box 203, Alice 78332; and professor, Dept. of Rangeland Ecology and Management, Texas A\&M University, College Station 77843.

Published with approval of the director, Texas Agr. Exp. Sta. as TA-27009.

Manuscript accepted 13 April 1991.
}

were associated with instantaneous intake rate (IIR) and instantaneous nutrient intake rate (INIR) by deer, and if IIR and INIR correlated to preference rankings by percent time spent foraging on a particular species and with amount of foliage consumed.

\section{Study Area and Methods}

The study was conducted on the Texas Agricultural Experiment Station's La Copita Research Area $\left(27^{\circ} 40^{\prime} \mathrm{N}, 98^{\circ} 12 \mathrm{~W}\right.$ ) about 15 $\mathrm{km}$ southwest of Alice, Texas, in Jim Wells County. Vegetation of La Copita is characteristic of the northern Tamaulipan thornscrub woodland. The climate is subtropical with hot, humid summers and mild winters with an average growing season of $>260$ days. Long-term mean precipitation is $716 \mathrm{~mm}$ with maxima in MayJune and September (Scifres and Koerth 1987).

Deer used in the trials were 3 male and 1 female yearlings ( 1 yr old at Trial 1). All deer were tame and readily accepted hand feeding. Deer were held in a 0.2 -ha pen containing some native woody and herbaceous plants but primarily maintained on a commercially available pelleted feed. While in the holding pen, all deer were introduced to hand feeding of cut branches of the various plant species. The deer also were trained to feed from branches stapled to sawhorses used in our preference trials. Habituation was started as soon as the deer were completely weaned from bottle feeding as learning and experience early in life may influence preferences or aversions and enables young animals to acquire necessary skills to efficiently harvest different forages (Provenza and Balph 1988). McMahan (1964) felt that feeding behavior and plant selection by experienced tame white-tailed deer were similar to those of their wild counterparts.

\section{Instantaneous Intake}

To estimate IIR, 9 browse species known to be eaten by whitetailed deer in south Texas (Everitt and Drawe 1974, Arnold and Drawe 1979) were used and included guajillo (Acacia berlanderi Benth.), huisache (A. farnesiana (L.) Willd.), blackbrush (A. rigidula Benth.), Texas persimmon (Diospyros texana Scheele), spiny hackberry (Celtis pallida Torr.), brasil (Condalia obovata Hook.), coma (Bumelia celastrina H.B.K.), lime pricklyash (Zanthoxylum fagara (L.) Sarg.), and kidneywood (Eysenhardtia texana Scheele). For the instantaneous intake trials the deer were confined in an $8 \times$ 5 -m pen divided into 2 sections. Individual deer could be penned in 1 section for feeding. Five branches (terminal $50 \mathrm{~cm}$ ) of each browse species were offered separately to each of 4 deer for $30 \mathrm{sec}$ during each trial. Branches were held in a horizontal position about $0.5 \mathrm{~m}$ above the ground. Branches were selected from plants growing adjacent to the holding pen to minimize weight loss through desiccation. Branches were weighed to the nearest $0.01 \mathrm{~g}$ immediately before and after offering to determine intake. Branches were of sufficient size so that no more than a mean of about $25 \%$ of the available material of any species was consumed within the time period (range 7.0 to $23.9 \%$ ) (Table 1). Trials were conducted during major morning or evening feeding periods during 3 times of the year representing major growth phases of the woody plants. To minimize selection bias by deer, the same species was offered to each deer and only 1 species/day was used. Trial 1 was in June 1988 during stem elongation of the browse. Trial 2 was in August 1988 
Table 1. Mean mass (g) and standard error (SE) of herbage on 20 branches/species of browse before and after offering to deer to determine instantaneous intake rate during 3 plant development stages on La Copita Research Area.

\begin{tabular}{|c|c|c|c|c|c|c|c|c|c|c|c|c|}
\hline \multirow[b]{2}{*}{ Species } & \multicolumn{4}{|c|}{ New leaf development } & \multicolumn{4}{|c|}{ Stem elongation } & \multicolumn{4}{|c|}{ Full leaf development } \\
\hline & Before & SE & After & SE & Before & SE & After & $\mathrm{SE}$ & Before & SE & After & SE \\
\hline & (g) & & (g) & & (g) & & (g) & & (g) & & (g) & \\
\hline Spiny hackberry & 27.4 & 2.3 & 23.5 & 2.2 & 38.7 & 2.9 & 32.9 & 2.7 & 34.7 & 2.1 & 29.4 & 1.9 \\
\hline Brasil & 31.5 & 2.1 & 28.2 & 2.0 & 30.4 & 1.7 & 27.6 & 1.7 & 39.1 & 2.2 & 35.1 & 2.1 \\
\hline Guajillo & 32.2 & 2.3 & 24.5 & 2.4 & 29.3 & 2.2 & 22.5 & 1.9 & 43.4 & 1.9 & 35.1 & 2.2 \\
\hline Texas persimmon & 37.1 & 2.5 & 34.5 & 2.3 & 41.2 & 3.2 & 36.9 & 3.1 & 25.9 & 1.6 & 23.9 & 1.6 \\
\hline Lime pricklyash & 30.2 & 1.9 & 25.5 & 1.7 & 29.8 & 1.9 & 23.7 & 1.9 & 35.9 & 1.9 & 29.3 & 1.8 \\
\hline Blackbrush & 25.6 & 1.5 & 23.8 & 1.4 & 23.2 & 1.4 & 20.7 & 1.3 & 49.5 & 2.9 & 44.0 & 2.9 \\
\hline Coma & 26.5 & 2.0 & 23.6 & 1.9 & 16.8 & 1.2 & 14.2 & 1.1 & 33.5 & 2.1 & 31.0 & 2.2 \\
\hline Huisache & 27.6 & 1.3 & 24.2 & 1.3 & 9.5 & 0.6 & 7.7 & 0.6 & 20.9 & 1.5 & 15.1 & 1.3 \\
\hline Kidneywood & 12.5 & 0.8 & 11.2 & 0.9 & 18.5 & 1.1 & 16.2 & 1.1 & 16.1 & 1.3 & 14.2 & 1.1 \\
\hline
\end{tabular}

during full leaf development. Trial 3 was in May 1989 during new leaf development.

\section{Plant Morphology}

To evaluate how morphological characteristics correlated to IIR and INIR, 10 branches of each browse species were measured for thorn density (number $/ 20-\mathrm{cm}$ terminal segment), total weight of green leaves, and leaf weight/stem weight ratio. Mean leaf length was taken from Vines (1960).

\section{Nutrient Concentration}

Quality of woody plant foliage was estimated from handplucked samples of each species collected immediately after observing the feeding behavior of the deer during the intake trials. Care was taken to select only plant parts actually eaten by deer. Grab samples were dried for 48 hours at $50^{\circ} \mathrm{C}$ and then ground in a Wiley mill to pass a $1-\mathrm{mm}$ screen. Diet quality analysis included percent crude protein (CP), neutral detergent fiber (NDF), acid detergent fiber (ADF), and acid detergent fiber nitrogen (ADFN) and was expressed on an organic matter (OM) basis. Crude protein was determined using standard micro-kjeldahl techniques (A.O.A.C. 1970). Neutral detergent fiber, ADF, and ADFN were determined by nonsequential procedures of Goering and Van Soest (1970). Estimates of INIR were derived by multiplying nutrient concentrations $(\mathrm{g} / 100 \mathrm{~g} \mathrm{OM})$ by the recorded intake rate $(\mathrm{g} / \mathrm{min})$.

\section{Preference Indices}

Preference indices were determined concurrently using 2 techniques by offering all 9 browse species to all deer simultaneously for $15 \mathrm{~min}$. Branches similar in size to those used in the intake trials were stapled to 2 sawhorses (approximately 2-m long and $0.5-\mathrm{m}$ high) so that the branches extended outward from both sides. Branches were of sufficient size so that no more than a mean of about $50 \%$ of available material of any species was consumed within the time period (range 2.6 to $51.4 \%$ ) (Table 2).
Four branches ( 1 for each deer) of each browse species were arranged randomly along the board. For the first technique, branches were weighed immediately before and after offering to determine the amount of material of each species consumed. Weights of material removed, calculated as a percentage of available material by species, were ranked and the species with the highest percentage of material removed was considered the most preferred. For the second technique, a preference index was determined using the amount of time spent browsing each species by recording which species each deer was eating at 15 -sec intervals. Percent time was ranked on a frequency basis and the species with the highest frequency was considered the most preferred.

\section{Statistical Analysis}

Data for IIR were analyzed by analysis of variance using the GLM procedure in SAS (SAS 1985). Instantaneous intake rate of browse species constituted the dependant variable, individual deer were used as replications, and species $X$ deer was used as the error term because species and deer did not interact $(F=1.27,24,8 \mathrm{df}, P$ $=0.23$ ). Following a significant $F$ test, the protected Least Significant Difference (LSD) procedure (Steel and Torrie 1960) was used to identify differences in means. Pearson rank correlation was used to determine relationships of IIR and INIR rankings to ranks of plant morphological attributes, and to the ranks of the 2 preference indices to examine the comparability of techniques. Because our plants showed little seasonal variation in leaf mass, leaf weight/stem weight ratio, and thorn density, correlations to IIR and INIR are presented only for 1 trial.

\section{Results and Discussion}

\section{Instantaneous Intake/Plant Morphology}

Of the plant morphological attributes considered, mean leaf mass and leaf weight $/$ stem weight ratio showed significant $(P<0.05)$ positive correlations ( $r=0.75$ and 0.65 , respectively) with IIR

Table 2. Mean mass (g) and standard error (SE) of herbage on 4 branches/species of browse before and after offering to deer to determine preference by amount of material consumed during 3 plant development stages in $L a$ Copital Research Area.

\begin{tabular}{|c|c|c|c|c|c|c|c|c|c|c|c|c|}
\hline \multirow[b]{2}{*}{ Species } & \multicolumn{4}{|c|}{ New leaf development } & \multicolumn{4}{|c|}{ Stem elongation } & \multicolumn{4}{|c|}{ Full leaf development } \\
\hline & Before & SE & After & SE & Before & SE & After & SE & Before & SE & After & SE \\
\hline & $(\mathrm{g})$ & & $(\mathrm{g})$ & & (g) & & (g) & & (g) & & $(\mathrm{g})$ & \\
\hline Spiny hackberry & 61.5 & 5.8 & 57.0 & 5.2 & 49.3 & 7.5 & 30.4 & 6.7 & 77.4 & 11.4 & 53.2 & 5.1 \\
\hline Brasil & 36.2 & 0.3 & 32.0 & 0.7 & 80.6 & 7.1 & 57.8 & 3.7 & 59.9 & 10.8 & 41.3 & 9.2 \\
\hline Guajillo & 36.2 & 5.5 & 28.5 & 6.8 & 45.5 & 5.6 & 31.4 & 4.6 & 35.9 & 7.2 & 17.6 & 0.6 \\
\hline Texas persimmon & 47.9 & 1.1 & 41.3 & 2.6 & 120.7 & 15.5 & 108.8 & 11.7 & 49.6 & 7.6 & 43.6 & 5.8 \\
\hline Lime pricklyash & 47.6 & 3.6 & 45.0 & 3.8 & 46.6 & 8.8 & 32.2 & 7.5 & 43.4 & 4.2 & 21.1 & 2.4 \\
\hline Blackbrush & 34.2 & 2.6 & 33.3 & 2.5 & 59.2 & 9.4 & 52.3 & 8.6 & 41.8 & 3.8 & 37.7 & 3.4 \\
\hline Coma & 54.9 & 3.8 & 49.9 & 3.4 & 60.0 & 5.5 & 47.8 & 6.0 & 33.0 & 2.8 & 24.4 & 1.7 \\
\hline Huisache & 26.9 & 2.1 & 25.1 & 1.7 & 32.0 & 5.0 & 27.1 & 4.2 & 29.5 & 6.4 & 23.6 & 5.6 \\
\hline Kidneywood & 46.7 & 3.4 & 43.9 & 3.0 & 33.6 & 4.6 & 29.9 & 4.4 & 21.1 & 2.1 & 15.1 & 0.8 \\
\hline
\end{tabular}


Table 3. Plant morphological attributes correlated with instantaneous intake rate (IIR) $(\mathrm{g} / \mathrm{min})$ of dry matter and instantaneous nutrient rate (INIR) (g nutrient/min) of crude protein (CP), neutral detergent fiber (NDF), acid detergent fiber (ADF), and acid detergent fiber nitrogen (ADFN) by white-tailed deer during Trial 1 on La Copita Research Area.

\begin{tabular}{lcccc}
\hline \hline & \multicolumn{4}{c}{ Plant attributes } \\
\cline { 2 - 5 } Species & $\begin{array}{c}\text { Leaf } \\
\text { mass }\end{array}$ & $\begin{array}{c}\text { Leaf } \\
\text { length }\end{array}$ & $\begin{array}{c}\text { Thorn } \\
\text { density }\end{array}$ & $\begin{array}{c}\text { Leaf/stem } \\
\text { ratio }\end{array}$ \\
\hline & $(\mathrm{g})$ & $(\mathrm{cm})$ & $(\mathrm{No} / 20 \mathrm{~cm})$ & \\
Spiny hackberry & 6.3 & 3.5 & 11.9 & 1.8 \\
Brasil & 6.0 & 2.3 & 16.5 & 1.0 \\
Guajillo & 4.8 & 12.7 & 0 & 2.1 \\
Texas persimmon & 4.6 & 4.0 & 0 & 0.4 \\
Lime pricklyash & 2.8 & 8.9 & 8.3 & 1.4 \\
Blackbrush & 2.7 & 1.7 & 36.4 & 0.7 \\
Coma & 2.3 & 2.5 & 7.3 & 0.5 \\
Huisache & 1.4 & 6.4 & 23.1 & 1.0 \\
Kidneywood & 1.1 & 4.5 & 0 & 0.3 \\
Correlation coef. (r) & & & & \\
for IIR & $0.75^{*}$ & 0.37 & -0.39 & $0.65^{*}$ \\
for INIR-CP & 0.50 & $0.67^{*}$ & -0.47 & 0.56 \\
for INIR-NDF & $0.73^{*}$ & 0.32 & -0.27 & 0.59 \\
for INIR-ADF & $0.73^{*}$ & 0.22 & -0.37 & 0.48 \\
for INIR-ADFN & $0.68^{*}$ & 0.53 & -0.30 & $0.81^{*}$ \\
\hline
\end{tabular}

Mean from terminal $20 \mathrm{~cm}$ of 10 randomly selected branches/species.

2 Mean leaf length from Vines (1960).

-Correlation coefficient significantly $(P<0.05)$ different from zero.

(Table 3). Mean leaf length and thorn density were uncorrelated. Species with growth forms that provided larger quantities of lush leaves at stem ends and with few or small stems were readily consumed. In free ranging goats, Hanley (1982) found the amount and accessibility of palatable forage influenced the degree of selectivity. Apparently the relatively small mouth size of deer and goats (Hanley 1982) is counter adapted to many plant defenses and allows for harvest of palatable plant parts despite presence of spines or thorns. This agrees in part with Hervey (1989), who found mean leaf size and leaf crown volume weight $\left(\mathrm{g} / \mathrm{m}^{3}\right)$ were highly correlated with IIR of deer and goats while spinescence and amount of volatile oils were poorly correlated. Likewise, Cooper and Owen-Smith (1986) observed that plant prickles, unless coupled with small leaf size, were ineffective in deterring browsing ungulates in Africa. Wickstrom et al. (1984) also found that dry matter intake by mule deer ( $O$. hemionus hemionus) was relatively insensitive to standing crop biomass.

Leaf mass also showed significant $(P<0.05)$ positive correlations with INIR of NDF ( $r=0.73)$, ADF $(r=0.73)$, and ADFN $(r=$ 0.68 ) (Table 3). Leaf length showed a significant $(P<0.05)$ correlation $(r=0.67)$ ith INIR of CP. While not significant $(P>0.05)$. thorn density tended to be negatively correlated to IIR and INIR.

Guajillo consistently ranked highest in IIR during all trials (Fig. 1). Although leaf length was poorly correlated to IIR (Table 3), guajillo's relatively long leaves, high leaf weight/stem weight ratio, and growth form where leaves and small twigs tend to be clustered on the terminal end of single large stems, likely presented the animals with large, leafy bites free from obstructions. Hervey (1989) found deer harvested guajillo almost 3.5 times greater than any other browse species tested. Lime pricklyash and spiny hackberry also were consistently prominent in IIR (Fig. 1). Although armed, both of these species exhibited a relatively high leaf weight/stem weight ratio (Table 3) allowing for a high intake rate. Texas persimmon ranked high during the stem elongation phase but dropped to a low level for the other 2 periods (Fig. 1). Hervey (1989) also found Texas persimmon to have a high IIR during June. Although persimmon had a high leaf mass, relatively large leaves, and no spinescence, the low leaf weight/stem weight ratio (Table 3 ) indicated animals would have to contend with numerous stems while browsing. Vines (1960) described the growth form of Texas persimmon as intricately branched. Possibly during the stem elongation phase, terminal branches were pliable and did not hinder browsing as extensively. Brasil and blackbrush had a high IIR only during the full leaf development stage (Fig. 1). Both of these species are highly armed and have relatively small leaves (Table 3). Full mature leaves may be necessary to allow efficient harvest. To illustrate this, mean intake rate of all 9 species was estimated at $7.0 \mathrm{~g} / \mathrm{min}$ during new leaf development, $7.8 \mathrm{~g} / \mathrm{min}$

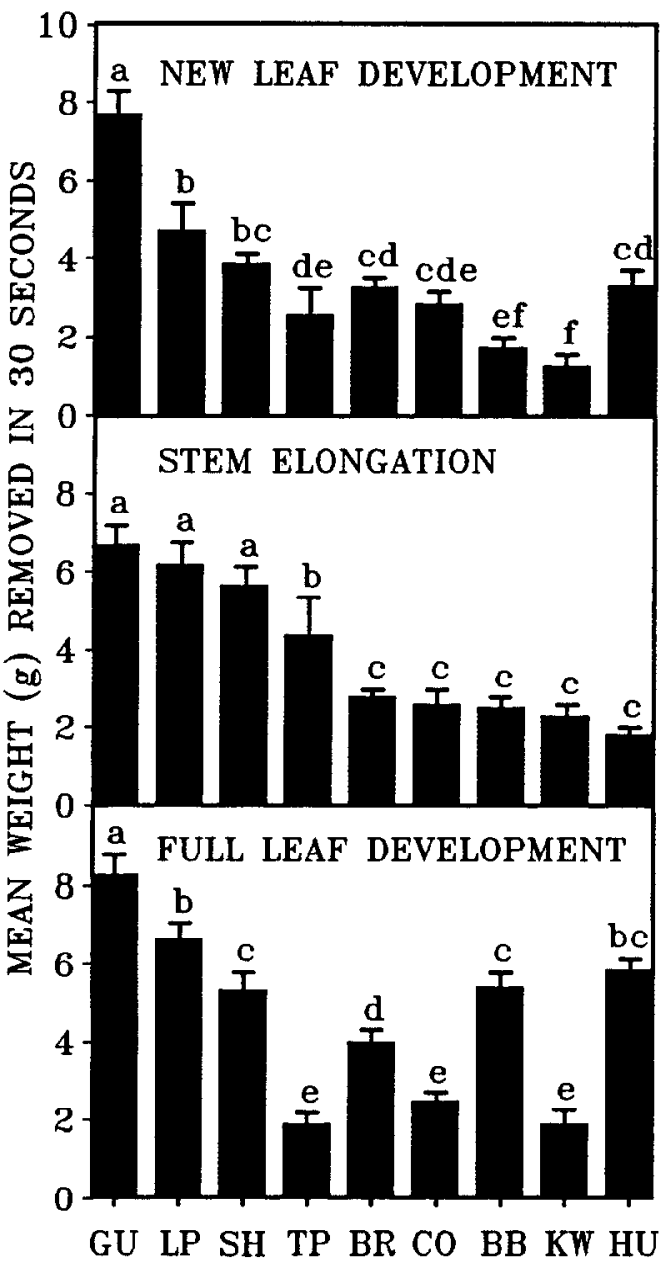

Fig. 1. Instantaneous intake rate (IIR) by white-tailed deer of 9 browse species during 3 plant development stages (mean and standard error). Different letters above bars indicate significant differences $(P<0.05)$ within a growth stage according to protected Least Significant Difference. $\mathrm{GU}=$ guajillo, $\mathrm{LP}=$ lime pricklyash, $\mathrm{SH}$ = spiny hackberry, $\mathrm{TP}=$ Texas persimmon, $\mathbf{B R}=$ brasil, $\mathbf{C O}=$ coma, $\mathbf{B B}=$ blackbrush, $\mathbf{K W}=$ kidneywood, and $\mathrm{HU}=$ huisache.

during stem elongation, and $9.2 \mathrm{~g} / \mathrm{min}$ when all species had attained mature status. Huisache, another prominently armed species with a low leaf weight/stem weight ratio, showed a high IIR during the full leaf stage but also was ingested relatively efficiently during new leaf development (Fig. 1). Instantaneous intake rate for coma and kidneywood was low for all trials.

\section{Instantaneous Intake/Nutrient Concentration}

Crude protein of the browse plants declined as the plants matured (Table 4). Verme and Ullrey (1974) estimated that dietary CP levels of 13-20\% are sufficient for growth and reproduction in white-tailed deer. All browse species maintained or exceeded required $\mathrm{CP}$ during the 3 growth stages, similar to findings of Everitt and Gonzalez (1981) and Meyer and Brown (1985). 
Table 4. Crude protein (CP), neutral detergent fiber (NDF), acid detergent fiber (ADF), and acid detergent fiber nitrogen (ADFN) of 9 browse species used to determine instantaneous intake rate (IIR) ( $8 / \mathrm{min}$ ) of white-tailed deer during 3 plant development stages (\% organic matter basis).

\begin{tabular}{|c|c|c|c|c|c|c|c|c|c|c|c|c|}
\hline \multirow[b]{2}{*}{ Species } & \multicolumn{4}{|c|}{ New leaf development } & \multicolumn{4}{|c|}{ Stem elongation } & \multicolumn{4}{|c|}{ Full leaf development } \\
\hline & $\mathrm{CP}$ & NDF & ADF & ADFN & $\mathrm{CP}$ & NDF & ADF & ADFN & $\mathbf{C P}$ & NDF & ADF & ADFN \\
\hline & $(\%)$ & $(\%)$ & $(\%)$ & $(\%)$ & $(\%)$ & $(\%)$ & $(\%)$ & $(\%)$ & (\%) & $(\%)$ & $(\%)$ & $(\%)$ \\
\hline Spiny hackberry & 32.3 & 37.4 & 21.1 & 6.8 & 27.7 & 42.7 & 25.2 & 4.0 & 24.1 & 35.2 & 20.6 & 3.6 \\
\hline Brasil & 20.1 & 44.5 & 27.4 & 3.3 & 16.3 & 43.2 & 23.9 & 3.8 & 13.8 & 38.2 & 24.1 & 4.2 \\
\hline Guajillo & 21.2 & 62.0 & 37.9 & 2.9 & 18.7 & 52.4 & 29.5 & 4.2 & 15.6 & 49.3 & 26.9 & 3.4 \\
\hline Texas persimmon & 15.4 & 53.8 & 39.3 & 1.1 & 12.8 & 47.7 & 35.2 & 1.6 & 13.8 & 43.4 & 33.6 & 1.9 \\
\hline Lime pricklyash & 24.8 & 31.9 & 19.5 & 5.0 & 18.9 & 27.2 & 19.9 & 3.3 & 18.5 & 33.5 & 23.4 & 2.4 \\
\hline Blackbrush & 17.0 & 64.2 & 57.6 & 2.7 & 13.3 & 56.6 & 43.1 & 2.5 & 15.8 & 55.6 & 43.4 & 3.1 \\
\hline Coma & 14.6 & 35.1 & 26.0 & 3.2 & 13.4 & 30.4 & 23.7 & 2.8 & 12.3 & 30.9 & 25.8 & 2.6 \\
\hline Huisache & 27.8 & 54.6 & 28.9 & 6.3 & 26.2 & 55.9 & 31.3 & 3.6 & 20.7 & 46.8 & 25.5 & $\begin{array}{l}2.0 \\
5.0\end{array}$ \\
\hline Kidneywood & 24.1 & 43.1 & 24.7 & 3.6 & 22.1 & 45.4 & 26.3 & 3.2 & 15.5 & 52.5 & 31.7 & 2.6 \\
\hline \multicolumn{13}{|l|}{ Correlation coef. } \\
\hline for IIR & 0.48 & -0.15 & 0.30 & 0.38 & -0.05 & -0.40 & -0.33 & 0.42 & 0.56 & -0.05 & -0.30 & 0.33 \\
\hline
\end{tabular}

Trends in NDF and ADF during the various growth stages were not distinct (Table 4). Several species unexpectedly exhibited a higher fiber content during new leaf development than during the more mature stages. This may be partially explained by far below normal precipitation (approximately $97 \%$ below long term monthly median) and above normal temperature during May 1989 (Table 5). Low moisture and high temperature may interact to increase

Table 5. Thirty year temperature (C) means and median precipitation (mm) from Alice, Texas and means for study period on La Copita Research Area.

\begin{tabular}{|c|c|c|c|c|c|c|}
\hline & \multicolumn{3}{|c|}{ Thirty year-mean } & \multirow[b]{2}{*}{$\begin{array}{l}\text { May } \\
1989\end{array}$} & \multirow[b]{2}{*}{$\begin{array}{l}\text { June } \\
1988\end{array}$} & \multirow[b]{2}{*}{$\begin{array}{l}\text { Aug } \\
1988\end{array}$} \\
\hline & May & June & $\overline{\text { Aug }}$ & & & \\
\hline High temperature $\left({ }^{\circ} \mathrm{C}\right)$ & 31.5 & 34.3 & 36.1 & 35.3 & 34.4 & 36.6 \\
\hline Low temperature $\left({ }^{\circ} \mathrm{C}\right)$ & 19.9 & 22.4 & 23.0 & 22.6 & 21.7 & 23.5 \\
\hline Precipitation (mm) & 73.4 & 71.6 & 34.0 & 2.5 & 53.8 & 28.7 \\
\hline
\end{tabular}

cell wall components through increased lignification and more rapid conversion of photosynthetic products to structural components despite plant age (Van Soest 1982). June and August 1988 had precipitation $25 \%$ and $16 \%$ below long-term monthly median, respectively, with average temperatures (Table 5). Meyer and Brown (1985) found lower NDF concentrations in some winter forages compared to autumn samples following rains that broke a summer-long drought. Nutrient and fiber concentrations in our study were not significantly $(P>0.05)$ correlated to IIR during any plant development stage (Table 4).

Acacia species (guajillo, huisache, and blackbrush) and Texas persimmon tended to possess the highest fiber concentrations throughout the growing season (Table 4). Even though deer ingested guajillo faster than the other browse species, the high fiber content would likely require more microbial cellulose digestion and longer retention time in the rumen. Schoonveld et al. (1974) felt the small rumen-reticula, omasa, and abomasa size of mule deer would prevent fibrous material from remaining in the rumen long enough for adequate digestion of lignified fiber. Fiber concentrations in lime pricklyash and spiny hackberry tended to be the lowest of all species tested indicating a relatively high availability of cell solubles. Low fiber, high IIR, and high CP content may make lime pricklyash and spiny hackberry the most profitable plants of the species studied for nutrient intake by deer. Meyer et al. (1984) also found spiny hackberry and lime pricklyash were high quality summer forages for deer.

\section{Instantaneous Intake/Preference Indices}

Instantaneous intake rate and INIR were poorly correlated with preference indices based on weight of forage removed and amount of time spent browsing (Table 6). A significant $(P<0.05)$ positive

Table 6. Pearson correlations of instantaneous intake rate (IIR) $(\mathrm{g} / \mathrm{min})$ and instantaneous nutrient intake rate (INIR) ( 8 nutrient/min) during 3 plant development stages and preference indices based on weight WT) of forage removed and time (TIM) spent browsing by white-tailed deer. Nutrients investigated included crude protein (CP), neutral detergent fiber (NDF), acid detergent fiber (ADF), and acid detergent fiber nitrogen (ADFN).

\begin{tabular}{lccc}
\hline \hline Comparison & $\begin{array}{c}\text { New leaf } \\
\text { development }\end{array}$ & $\begin{array}{c}\text { Stem } \\
\text { elongation }\end{array}$ & $\begin{array}{c}\text { Full leaf } \\
\text { development }\end{array}$ \\
\hline IIR with WT & 0.48 & $0.71^{*}$ & 0.20 \\
IIR with TIME & 0.48 & 0.39 & 0.23 \\
INIR-CP with WT & 0.47 & 0.35 & 0.45 \\
INIR-CP with TIME & 0.48 & -0.05 & 0.47 \\
INIR-NDF with WT & 0.38 & 0.53 & -0.05 \\
INIR-NDF with TIME & 0.32 & 0.22 & 0.15 \\
INIF-ADF with WT & 0.38 & 0.60 & 0.07 \\
INIR-ADF with TIME & 0.32 & 0.33 & 0.15 \\
INIR-ADFN with WT & 0.50 & $0.70^{*}$ & 0.22 \\
INIR-ADFN with TIME & 0.52 & 0.36 & 0.33 \\
WT with TIME & $0.73^{*}$ & $0.87^{*}$ & $0.70^{*}$ \\
\hline
\end{tabular}

* Correlation coefficient significantly $(P<0.05)$ different from zero.

correlation ( $r=0.71)$ was found between IIR and weight of forage removed only during the stem elongation stage. Positive correlations between weight removed and time spent browsing, however, were significant $(P<0.05)$ during all 3 plant growth stages $(r=0.73$ for new leaf development $r=0.87$ for stem elongation, and $r=0.70$ for full leaf development), indicating the 2 techniques closely agreed in species rankings.

A number of factors may affect preference and all relative preference indices have shortcomings (Krueger 1972, Cock 1978, Johnson 1980, Loehle and Rittenhouse 1982, Owen-Smith and Cooper 1987). A fundamental shortcoming of comparing usage and availability data to determine preference is the often arbitrary decision about the array of components actually available to an animal (Johnson 1980). Inclusion or exclusion of availability components can affect results. In determining preference indices in our study, availability components were set equal to each other within all trials. Our primary purpose was to rank the various species from most to least preferred under a specified condition. Use of rank data avoids absolute statements about preference or avoidance (Johnson 1980).

When presented with all browse species simultaneously, deer did not appear to select forages based solely on leaf size, spinescence, or possible rate of intake. Guajillo, for example, ranked first in IIR for all trials but ranked second to fourth in weight of forage 
removed and fourth to seventh in time spent browing (rank data not shown). Brasil, coma, spiny hackberry, and lime pricklypear consistently ranked first or second in weight removed or time spent browsing. Although brasil and coma had relatively low IIR, deer appeared to select for these species based on palatability factors not measured. Cooper and Owen-Smith (1986) found that intake rate was unrelated to acceptability of browse species for goats and impalas (Aepyceros melampus). For larger animals such as kudu (Tragelaphus strepsiceros), an intake rate of $<2 \mathrm{~g} / \mathrm{min}$ negatively influenced acceptance. Instantaneous intake rates among species in our study ranged from an estimated 2.6 to $16.6 \mathrm{~g} / \mathrm{min}$ (Fig. 1). Therefore, we assume the deer in our study were selecting forages based on factors other than potential intake rate.

Given a limited number of choices ( 9 species in our case) with little spatial variation, a purely generalist foraging strategy (Nudds 1980) would suggest the deer should respond by feeding randomly among the species offered. However, when deer were exposed to all browse species at once, feeding was not sequential from branch to branch. Rather, each animal appeared to avoid some species while accepting others. This is supported by our preference ranks showing some species were consumed more and maintained longer feeding durations than others. However, the deer did consume parts of all species presented. While not designed to examine foraging theory in detail, our results appear to support the concept that white-tailed deer are selective feeders and attempt to obtain a nutrient-optimizing diet within a fixed bulk of food (Nudds 1980).

\section{Literature Cited}

Arnold, L.A., Jr., and D.L. Drawe. 1979. Seasonal food habits of whitetailed deer in the south Texas plains. J. Range Manage. 32:175-178.

Association of Official Agricultural Chemists. 1970. Official methods of analysis (11th ed). Assoc. Off. Agr. Chem., Washington, D.C.

Chamrad, A.D., and T.W. Box. 1968. Food habits of white-tailed deer in south Texas. J. Range Manage. 21:158-164.

Cock, M.J.W. 1978. The assessment of preference. J. Anim. Ecol. 47:805-816.

Cooper, S.M., and N. Owen-Smith. 1986. Effects of plants spinescence on large mammalian herbivores. Oecologia. 68:446-455.

Davis, R.B. 1952. Use of rumen contents data in a study of deer-cattle competition and animal equivalence. Trans. North Amer. Wildl. Conf. $17: 448-458$.

Davis, R.B., and C.K. Winkler. 1968. Brush vs. cleared range as deer habitat in southern Texas. J. Wildl. Manage. 32:321-329.

Drawe, D.L. 1968. Mid-summer diet of deer on the Welder Wildlife Refuge. J. Range Manage. 21:164-166.

Everitt, J.H., and D.L. Drawe. 1974. Spring food habits of white-tailed deer in the south Texas plains. J. Range Manage. 27:15-20.

Everitt, J.H., and C.L. Gonzalez. 1981. Seasonal nutrient content in food plants of white-tailed deer on the south Texas plains. J. Range Manage. 34:506-510.
Goering, H.K., and P.J. Van Soest. 1970. Forage fiber analysis (apparatus, reagents, procedures, and some applications). ARS USDA Agr. Handb. 379.

Hanley, T.A. 1982. The nutritional basis for food selection by ungulates. J. Range Manage. 35:146-151.

Heady, H.F. 1964. Palatability of herbage and animal preference. J. Range Manage. 17:76-81.

Hervey, R.L. 1989. Effects of grazing pressure by angora goats on intra/interspecific foraging competition with white-tailed deer. MS Thesis, Texas A\&M Univ., College Station.

Johnson, D.N. 1980. The comparison of usage and availability measurements for evaluating resource preference. Ecology. 61:65-71.

Krueger, W.C. 1972. Evaluating animal forage preference. J. Range Manage. $25: 471-475$.

Loehle, C., and L.R. Rittenhouse. 1982. An analysis of forage preference indices. J. Range Manage. 35:316-319.

MeMahan, C.A. 1964. Comparative food habits of deer and three classes of livestock. J. Wildl. Manage. 28:798-808.

Meyer, M.W., and R.D. Brown. 1985. Seasonal trends in the chemical composition of ten range plants in south Texas. J. Range Manage. 38:154-157.

Meyer, M.W., R.D. Brown, and M.W. Graham. 1984. Protein and energy content of white-tailed deer diets in the Texas Coastal Bend. J. WildI. Manage. 48:527-534.

Nudds, T.D. 1980. Forage "preference": theoretical considerations of diet selection by deer. J. Wildl. Manage. 44:735-740.

Owen-Smith, N., and S.M. Cooper. 1987. Assessing food preferences of ungulates by acceptability indices. J. Wildl. Manage. 51:372-378.

Provenza, F.D., and D.F. Balph. 1988. Development of dietary choice in livestock on rangelands and its implications for management. J. Anim. Sci. 66:2356-2368.

Provenza, F.D., and D.F. Balph. 1990. Applicability of five diet-selection models to various foraging challenges ruminants encounter. p. 423-460. In: R.N. Hughes (ed.) Behavioral mechanisms of food selection. NATO ASI Series, Vol. G20. Springer Verlag, Berlin.

SAS. 1985. SAS user's guide: Statistics. Statistical Analysis Systems Institute, Inc. Cary, N.C.

Schoonveld, G.G., J.G. Nagy, and J.A. Bailey. 1974. Capability of mule deer to utilize fibrous alfalfa diets. J. Wildl. Manage. 38:823-829.

Scifres, C.J., and B.H. Koerth. 1987. Climate, soils, and vegetation of the La Copita Research Area. Tex. Agr. Exp. Sta. Misc. Pub. MP-1626.

Steel, R.G., and J.H. Torrie. 1960. Principles and procedures of statistics. McGraw-Hill, Inc. N.Y.

Van Soest, P.J. 1982. Nutritional ecology of the ruminant. O \& B Books, Inc., Corvallis, Ore.

Verme, L.J., and D.E. Ullrey. 1974. Feeding and nutrition of deer. In: D.C. Church (ed.) Digestive physiology and nutrition of ruminants. Vol. III. Practical nutrition. Oxford Press. Portland, Ore.

Vines, R. 1960. Trees, shrubs and woody vines of the Southwest. Univ. Texas Press, Austin.

Wickstrom, M.L., C.T. Robbins, T.A. Hanley, D.E. Spalinger, and S.M. Parish. 1984. Food intake and foraging energetics of elk and mule deer. J. Wildl. Manage. 48:1285-1301.

Willms, W. 1978. Foraging strategy of ruminants. Rangeman's Journal. 5:72-74. 